\title{
A Comparison of the Acute Phase Proteins in Chronic Aortic Occlusion versus Diffuse Aortoiliac Occlusive Disease
}

\author{
Nikola S. Ilićl,2, Igor B. Končar ${ }^{1,2}$, Marko V. Dragašl,2, \\ Milka T. Golubovićc ${ }^{3}$, Miroslav D. Marković, ${ }^{1,2}$, Miloš M. Sladojević1, \\ Slobodan D. Cvetković1,2, Lazar B. Davidović1,2 \\ ${ }^{1}$ Clinic of Vascular and Endovascular Surgery, Clinical Center of Serbia, Belgrade, Serbia; \\ ${ }^{2}$ Faculty of Medicine, University of Belgrade, Belgrade, Serbia; \\ ${ }^{3}$ Department of Biochemistry, Clinical Center of Serbia, Belgrade, Serbia
}

\section{SUMMARY}

Background The purpose of the present study is to evaluate if there is a specific relationship of the acute-phase proteins between patients with the chronic aortic occlusion (COA) and patients with diffuse aortoiliac occlusive disease (AIOD), and to investigate if there is a correlation between the acute phase proteins and the extent of disease.

Methods Sixty patients with the aortoiliac occlusive disease were divided in two groups. First group consisted of thirty patients with the angiographic signs of diffuse aortoiliac occlusive disease, Leriche type III (AIOD group). Second (COA) group consisted of 30 patients characterized by either bifurcated aortic occlusion or juxtarenal aortic occlusion. Those two groups were compared according to symptomatology, ankle-brachial index (ABI) values, traditional risk factors and some acute phase proteins (high-sensitivity C-reactive protein - hs-CRP; homocysteine) taken at inclusion.

Results The median serum hs-CRP was $4.85 \mathrm{mg} / \mathrm{L}$ and $15.7 \mathrm{mg} / \mathrm{L}$ in AIOD group and COA group, respectively. The difference was statistically significant $(p=0.016)$. The mean plasma homocysteine was $21.44 \pm 11.25 \mathrm{mmol} / \mathrm{L}$ and $14.76 \pm 7.85 \mathrm{mmol} / \mathrm{L}$ in the AIOD group and COA group, respectively. Mean plasma homocysteine was significantly higher in patients with AIOD $(p=0.005)$.

Conclusions Our data demonstrate significant difference in hs-CRP and homocysteine concentrations among two variants of aortoiliac occlusive disease. In this particular pathology as COA, high hs-CRP concentration does not associate, at least with the angiographic extent of disease.

Keywords: chronic aortic occlusion; acute phase proteins 


\section{INTRODUCTION}

Increasing evidence suggests that elevated levels of the acute-phase proteins occur in the acute coronary syndromes, carotid disease and aortoiliac occlusive disease and may also predict future cardiovascular events [1-4]. On the other hand, there are many controversial reports as to whether inflammatory markers are the cause or the result of atherosclerosis. Consequently, circulating factors related to inflammation may be potential predictors of atherosclerosis. It has been shown that the only acute phase protein independently associated with cerebrovascular diseases was fibrinogen [5]. On the other hand, high-sensitivity C-reactive protein (hs-CRP) does seem to be associated with plaque density, especially at the femoral level, which supports the previously described link between C-reactive protein (CRP) and peripheral arterial disease while plasma homocysteine levels are related to the extent of atherosclerosis in coronary and peripheral arteries. Measurements of CRP and homocysteine with high sensitive techniques, with low detection levels, have attracted a lot of attention and those two acute-phase proteins are more often connected with the extent of peripheral disease. Chronic aortic occlusion (COA) is a rare condition, confined to the aortic bifurcation or juxtarenal position with usually spared distal vascular tree [6]. Contrary, diffuse aortoiliac occlusive disease (AIOD) is more pronounced, affecting infrainguinal segment additionally. The only connection between these two variants of disease is the same degenerative etiology. To the best of our knowledge, studies which considered formal assessment of similarities in inflammatory markers between COA and AIOD have not been previously undertaken.

The purpose of the present study is to evaluate if there is a specific relationship of the acute phase proteins between those two variants of the same disease and to investigate if there is a connection between the acute phase proteins and the extent of disease.

\section{MATERIAL AND METHODS}

This study is a part of academic (noncommercial) phase IV prospective study, carried out in compliance with the EU Directives of clinical trials [7]. Informed consent was obtained from each subject enrolled in the study. The study was approved by the Institutional Ethics Board of the Clinical Center of Serbia.

From January 2009 to January 2011, 351 patients with symptomatic peripheral arterial disease were enrolled at Clinic of Vascular and Endovascular Surgery, Clinical Center of Serbia, Belgrade, Serbia. All patients underwent translumbar aortography since multi slice computed tomography (MSCT) is not always available due to technical reasons. Out of them, 60 patients with the aortoiliac occlusive disease were divided into two groups. First AIOD group consisted of 30 patients with the angiographic signs of diffuse aortoiliac occlusive disease, Leriche type III with the affected femoropopliteal segment. These patients had to fulfill following criteria: 1) diminished but present femoral pulses confirmed by spectral analysis measurements; 2) angiographic signs of diffuse aortoiliac occlusive disease but without occlusion. Second COA group consisted of 30 patients characterized by either bifurcated aortic occlusion or juxtarenal aortic occlusion, based on the level of proximal extension of the chronic athero-thrombotic material and level of disruption of the contrast column on standard translumbar aortography. All patients but six from COA group had a patent femoropopliteal segment. Iliac artery segment was spared in all patients from COA group. Patients were excluded from this study if they had: 1) open or endovascular lower limb revascularization; 2) acute abdominal aortic occlusion; 3 ) inflammatory etiology of COA; 4) type I or II Leriche disease. At the time of the aortogram, the presence of classic atherosclerotic risk factors, smoking, hypertension, dyslipidemia and diabetes as well as inflammatory markers were assessed. Those two groups were compared according to symptomatology, ankle-brachial index $(\mathrm{ABI})$ values, traditional risk factors and some acute phase proteins (hs-CRP, homocysteine). All patients diagnosed with any chronic inflammatory disease or acute infectious process and those who had fever physical trauma or had undergone surgery in the previous 45 days were excluded from the sample. Aortic reconstruction included aortobifemoral using gelatin sealed polyester prosthesis. $16 \times 8 \mathrm{~mm}$ bifurcated grafts were employed in all operations.

\section{Inflammatory markers level}

For blood collection, a 21-guage butterfly needle was inserted into an antecubital vein, and the 
tourniquet was removed immediately. Blood was spun at $3000 \mathrm{rpm}$ for 20 minutes at $4^{\circ} \mathrm{C}$ in a refrigerated centrifuge. Within 90 minutes off collection, processing and storage in $\mathrm{a}-70^{\circ} \mathrm{C}$ freezer was accomplished.

Homocysteine was measured in serum, using HPLC method with fluorescence detection (Varian, Inc.).

Hs-CRP levels were determined using an immunotechnique on the Olympus AU 680 system with the Olympus reagents.

\section{Statistical analysis}

Summarizing data were displayed as mean and standard deviation (SD) or median (range). Continuous normally distributed variables were compared using Student's t-test or the MannWhitney U-test for non-normally distributed variables. Differences among categorical variables were analyzed using the Chi-square test or the two-tailed Fisher's exact test, as appropriate. P-values less than 0.05 were considered statistically significant. Statistical analysis was carried out using the SPSS 15 software (SPSS, Chicago, IL, USA).

\section{RESULTS}

These two groups were homogenous except patients from COA group who were younger, while some traditional risk factors were $(\mathrm{p}<0.001)$ more pronounced in AIOD group. Demographic characteristics, comorbid conditions and traditional risk factors were shown in Table 1.

There were highly significant differences in ABIs between the AIOD and COA patients $(\mathrm{p}=0.013)$ (Table 2). Furthermore, claudications were dominant symptomatology in COA group, while severe ischemia (grade III and IV) was more pronounced in AIOD group $(\mathrm{p}=0.001)$ (Table 2).

The median serum hs-CRP was $4.85 \mathrm{mg} / \mathrm{L}$ (range: $0.2-45.8 \mathrm{mg} / \mathrm{L}$ ) and $15.7 \mathrm{mg} / \mathrm{L}$ (range: 0.79-134.0 mg/L) in AIOD and COA group, respectively; the difference was significant $(\mathrm{p}=0.016)$ (Table 3$)$. The median level of plasma

Table 1. Demographic, comorbid data and traditional risk factors

\begin{tabular}{lccc} 
Variable & AIOD group $(\mathbf{n = 3 0})$ & COA group $(\mathbf{n = 3 0})$ & p \\
\hline Age (years) & $64.86 \pm 7.22$ & $56.73 \pm 6.86$ & $<0.001^{*}$ \\
Male gender & $23(76.7 \%)$ & $23(76.7 \%)$ & 1.000 \\
Hypertension & $30(100.0 \%)$ & $25(83.3 \%)$ & $0.026^{*}$ \\
Smoking & $23(76.7 \%)$ & $24(80.0 \%)$ & 0.754 \\
Diabetes & $8(26.7 \%)$ & $6(20.0 \%)$ & 0.542 \\
Carotid disease & $13(43.3 \%)$ & $13(43.3 \%)$ & 1.000 \\
Coronary disease & $8(26.7 \%)$ & $9(30.0 \%)$ & 0.774 \\
Cholesterol (mmol/L) & $6.12 \pm 1.26$ & $5.53 \pm 1.20$ & 0.062 \\
LDL-cholesterol (mmol/L) & $3.87 \pm 1.14$ & $3.60 \pm 1.02$ & 0.278 \\
Triglycerides (mmol/L) & $1.76 \pm 0.52$ & $1.96 \pm 0.83$ & 0.412 \\
HDL-cholesterol (mmol/L) & $1.20 \pm 0.31$ & $1.02 \pm 0.26$ & $0.027^{\star}$ \\
\hline
\end{tabular}

Values are expressed as mean $\pm \mathrm{SD}$, or number of patients (\%).

* significant difference

AIOD - aortoiliac occlusive disease; COA - chronic aortic occlusion; $n$ - number of patients

Table 2. Symptomatology and preoperative ABI values

\begin{tabular}{lccc} 
Variable & AIOD group $(\mathbf{n = 3 0})$ & COA group $(\mathbf{n = 3 0})$ & $\mathbf{p}$ \\
Claudication & $10(33.3 \%)$ & $24(80.0 \%)$ & \\
Rest pain & $12(40.0 \%)$ & $4(13.3 \%)$ & $0.001^{*}$ \\
Gangrene & $8(26.6 \%)$ & $2(6.7 \%)$ & \\
ABI & $0.44 \pm 0.08$ & $0.35 \pm 0.1$ & $0.013^{*}$ \\
\hline
\end{tabular}

Values are expressed as mean \pm SD, or number of patients (\%).

* significant difference

$A B I$ - ankle-brachial index 
Table 3. Acute phase proteins between two groups of patients

\begin{tabular}{lccc} 
Variable & AIOD group $(\mathbf{n = 3 0})$ & COA group $(\mathbf{n}=\mathbf{3 0})$ & $\mathbf{p}$ \\
hs-CRP $(\mathrm{mg} / \mathrm{L})$ & 4.85 (range: $0.2-45.8)$ & 15.7 (range: $0.79-134.0)$ & $0.016^{\star}$ \\
Homocysteine $(\mathrm{mmol} / \mathrm{L})$ & $21.44 \pm 11.25$ & $14.76 \pm 7.85$ & $0.005^{*}$ \\
\hline
\end{tabular}

Values are expressed as mean \pm SD, or median (range).

* significant difference

hs-CRP - high-sensitivity C-reactive protein

homocysteine was $21.44 \pm 11.25 \mathrm{mmol} / \mathrm{L}$ and $14.76 \pm 7.85 \mathrm{mmol} / \mathrm{L}$ in AIOD group and COA group, respectively. Mean plasma homocysteine was significantly higher in patients with AIOD $(\mathrm{p}=0.005)$ (Table 3$)$.

\section{DISCUSSION}

This study evaluated the inflammatory profile of patients with the aortoiliac occlusive disease by comparing two groups of patients with the same degenerative etiology and assessed the association between the acute phase proteins and the extent of atherosclerotic disease. As demonstrated by our data and those of other investigators, COA tends to occur in relatively young patients who have a history of tobacco abuse $[6,8]$. Hypertension and cholesterol individually have been shown to be significant clinical hemodynamic risk factors of atherosclerosis-related disease as we confirmed in our study as well. Both risk factors dominated in AIOD group but, to our opinion, a possible reason for higher number of patients with hypertension in AIOD group may be fairly older population which had more time to develop it. Our data showed that patients with the aortoilac occlusive disease had increased serum hs-CRP but significantly more pronounced in COA group. This is a new and interesting finding which may suggest that high baseline serum hs-CRP may identify patients who are most likely to develop COA or experience accelerated atherosclerosis of the native lower limb arteries. On the other hand, someone might argue that it is equally plausible that total aortic occlusive process is what caused the finding of high hs-CRP level. However, some previous studies have indicated an association between the elevated systemic hs-CRP levels and the impairment of endothelium-dependent vasorelaxation $[9,10,11]$. Contrary to initial thoughts, generated by previous trials, the novel study showed that hs-CRP did not impair an endothelium-dependent vasorelaxation and, fur- thermore, that CRP was not a vasoconstrictor but an endothelium-independent vasodilator [12]. It is interesting that high concentrations of hs-CRP are detected in COA group where distal arterial tree is usually spared of atherosclerosis, so it might be speculated than that the direct vasorelaxing effect of hs-CRP in patients with COA might be compensated response for massive thrombotic occlusion, thus allowing the hyperemic response, keeping distal vasculature patent and free of atherosclerosis. Furthermore, hs-CRP was inversely related to ABI. This is in agreement with previous studies showing that hs-CRP is associated with hemodynamic [13] and functional [14] outcomes and with the clinical severity of peripheral arterial disease [15]. These patients should be considered to be at high risk of future complications according to guidelines from the American Heart Association and the Centers for Disease Control and Prevention [16]. Similar to other investigations $[17,18]$, this study shows hyperhomocysteinaemia in both groups, but significantly higher mean plasma homocysteine concentration in patients with the advanced ischemia. These data suggest that hyperhomocysteinaemia may either be a marker of AIOD, or etiologically implicated in development of AIOD. Thus, this study does not establish elevated plasma homocysteine as a risk factor of atherosclerosis but there is a significant correlation with the extent of disease which is compatible with other studies. Additionally, the data herein confirm elevated plasma homocysteine as a risk factor of symptomatic atherosclerosis. It is not known how a moderate increase in plasma homocysteine is related atherogenic process in man. Several mechanisms could be involved: hyperhomocysteinaemia may cause endothelial damage and proliferation of smooth muscle cells in the intima [19]. This may lead to lipid accumulation in the arterial wall under hypercholesterolaemic conditions [20].

The association of elevated CRP levels in patients with distal aortic occlusion comparing with AIOD is a novelty, and it may be affected 
by patient selection and very small sample size. That is one of the major limitations of our study.

\section{CONCLUSIONS}

In conclusion, our data demonstrate significant difference of hs-CRP and homocysteine concentrations among two variants of aortoiliac occlusive disease. In this particular pathology as COA, high hs-CRP concentration does not associate, at least with angiographic extent of disease.

\section{Conflict of Interest Statement}

The authors certify that there are no potential conflicts of interest.

\section{REFERENCES}

1. Tracy RP, Lemaitre RN, Psaty BM, Ives DG, Evans RW, Cushman M, et al. Relationship of C-reactive protein to risk of cardiovascular disease in the elderly: results from the Cardiovascular Health Study and the Rural Health Promotion Project. Arterioscler Thromb Vasc Biol. 1997; 17:1121-7.

2. Kuller LH, Tracy RP, Shaten J, Meinhahn EN. Relation of C-reactive protein and coronary artery disease in the MRFIT nested case-control study. Am J Epidemiol. 1996; 144:537-47.

3. Ridker PM, Cushman M, Stampfer MJ, Tracy RP, Hennekens $\mathrm{CH}$. Inflammation, aspirin, and risks of cardiovascular disease in apparently healthy men. N Engl J Med. 1997; 336:973-9.

4. Ridker PM, Cushman M, Stampfer MJ, Tracy RP, Hennekens $\mathrm{CH}$. Plasma concentration of C-reactive protein and risk of developing peripheral vascular disease. Circulation. 1998; 97:425-8.

5. Ebrahim S, Papacosta O, Whincup P, Wannamethee G, Walker M, Nicolaides AN, et al. Carotid plaque, intima media thickness, cardiovascular risk factors, and prevalent cadiovascular disease in men and women. The British Regional Heart Study. Stroke. 1999; 30:841-50.

6. Ilić N, Davidović L, Končar I, Dragaš M, Marković $M$, Čolić M, et al. The benefits of internal thoracic artery catheterization in patients with chronic abdominal aortic occlusion. Cardiovasc Interv Radiol. 2011; 34:396-400.

7. European Parliament and the Council of the European Union Directive 2001/20/EC of the European Parliament and of the Council on the approximation of the laws, regulations and administrative provisions of the member states relating to implementation of good clinical practice in the conduct of clinical trials on medical products for human use. May, 2001. Available from: http://www.eort.be/services/ Doc/clinical-eu-directive-04-aprol1.pdf [accessed May 16, 2003].

8. Deriu GP, Ballota E. Natural history of ascending thrombosis of the abdominal aorta. Am J Surg. 1983; 145:652-7.

9. Cleland SJ, Sattar N, Petrie JR, Forouhi NG, Elliott $\mathrm{HL}$, Connell JM. Endothelial dysfunction as a possible link between C-reactive protein levels and cardiovascular disease. Clin Sci (Lond). 2000; 98:531-5.

10. Fichtlscherer S, Rosenberger G, Walter DH, Breuer S, Dimmeler S, Zeiher AM. Elevated C-reactive protein levels and impaired endothelial vasoreactivity in patients with coronary artery disease. Circulation. 2000; 102:1000-6.

11. Tomai F, Crea F, Gaspardone A, Versaci F, Ghini AS, Chiariello L, et al. Unstable angina and elevated c-reactive protein levels predict enhanced vasoreactivity of the culprit lesion. Circulation. 2001; 104: 1471-6.

12. Sternik L, Samee S, Schaff HV, Zehr KJ, Lerman LO, Holmes DR, et al. C-reactive protein relaxes human vessels in vitro. Arterioscler Thromb Vasc Biol. 2002; 22(11):1865-8.

13. McDermott MM, Green D, Greenland P, Liu K, Criqui MH, Chan C, et al. Relation of levels of hemostatic factors and inflammatory markers to the ankle brachial index. Am J Cardiol. 2003; 92:194-9.

14. McDermott MM, Greenland P, Green D, Guralnik JM, Criqui MH, Liu K, et al. D-dimer, inflammatory markers, and lower extremity functioning in patients with and without peripheral arterial disease. Circulation. 2003; 107:3191-8.

15. Majewski W, Zielinski A, Laciak M, Staniszewski $\mathrm{R}$, Gorny A, Zapalski S, et al. C-reactive protein and alpha-1-acid glycoprotein in monitoring of patients with chronic arterial occlusion of the lower limbs. Eur J Vasc Surg. 1993; 7:628-32.

16. Pearson TA, Mensah GA, Alexander RW, Anderson $J \mathrm{~L}$, Cannon RO III, Criqui M, et al. Markers of inflammation and cardiovascular disease: application to clinical and public health practice - a statement for healthcare professionals from the Centers for Disease Control and Prevention and the American Heart Association. Circulation. 2003; 107:499-511.

17. Mölgaard J, Malinow MR, Lassvik C, Holm AC, Upson B, Olsson AG. Hyperhomocyst(e)inaemia: an independent risk factor for intermittent claudication. J Intern Med. 1992; 231(3):273-9.

18. Fryer RH, Wilson BD, Gubler DB, Fitzgerald LA, Rodgers GM. Homocysteine, a risk factor for premature vascular disease and thrombosis, induces tissue factor activity in endothelial cells. Arterioscler Thromb. 1993; 13(9):1327-33.

19. Harker LA, Ross R, Slichter SJ, Scott CR. Homocysteine induced arteriosclerosis. The role of endothelial cell injury and platelet response in its genesis. Clin Invest. 1976; 58:731-41.

20. Minick CR, Stemerman MB, Insull W Jr. Role of endothelium and hypercholesterolemia in intimal thickening and lipid accumulation. Am Pathol. 1979; 95:131-58. 


\title{
Poređenje akutnih faznih proteina kod bolesnika s hroničnom okluzijom abdominalne aorte i difuznom aortoilijačnom okluzivnom bolešću
}

\author{
Nikola S. Ilić ${ }^{1,2}$, Igor B. Končar ${ }^{1,2}$, Marko V. Dragaš ${ }^{1,2}$, Milka T. Golubović3 \\ Miroslav D. Marković́1,2, Miloš M. Sladojević ${ }^{1}$, Slobodan D. Cvetković́, \\ Lazar B. Davidović1,2 \\ ${ }^{1}$ Klinika za vaskularnu i endovaskularnu hirurgiju, Klinički centar Srbije, Beograd, Srbija; \\ ${ }^{2}$ Medicinski fakultet, Univerzitet u Beogradu, Beograd, Srbija; \\ ${ }^{3}$ Centar za biohemiju, Klinički centar Srbije, Beograd, Srbija
}

\section{KRATAK SADRŽAJ}

Uvod Cilj ove studije bio je da se uporede akutni fazni proteini kod bolesnika s hroničnom okluzijom abdominalne aorte i difuznom aortoilijačnom bolešću, te ispita njihova korelacija sa distribucijom bolesti.

Metode Studija je obuhvatila 60 osoba s aortoilijačnom okluzivnom bolešću koje su svrstane u dve grupe od po 30 bolesnika. Prvu grupu činili su ispitanici sa difuznom aortoilijačnom okluzivnom bolešću (grupa AIOD), a drugu (grupa COA) bolesnici sa bifurkacionom ili jukstarenalnom okluzijom abdominalne aorte. Ove dve grupe su poređene prema simptomatologiji, vrednostima dopler indeksa $(A B I)$, tradicionalnim faktorima rizika i nekim akutnim faznim proteinima (visoko senzitivni C-reaktivni protein - hs-CRP; homocistein).

Rezultati Medijana vrednosti hs-CRP u grupi AIOD bila je 4,85 mg/l, a u grupi COA 15,7 mg/l. Ova razlika bila je statistički značajna $(p=0,016)$. Srednja vrednost homocisteina u plazmi u grupi AIOD bila je 21,44 $\pm 11,25 \mathrm{mmol} / \mathrm{l}$, a u grupi COA 14,76 $\pm 7,85 \mathrm{mmol} / \mathrm{l}$. Utvrđena je statistički značajno veća koncentracija ovog akutnog faznog proteina u grupi AIOD $(p=0,005)$.

Zaključak Naši podaci ukazuju na značajnu razliku u vrednostima hs-CRP i homocisteina između dve grupe ispitanika s aortoilijačnom okluzivnom bolešću. Visoke vrednosti hs-CRP nisu u korelaciji sa stepenom angiografske distribucije bolesti kod bolesnika iz grupe COA.

Ključne reči: hronična okluzija abdominalne aorte; akutni fazni proteini 